\title{
UPAYA MENINGKATKAN PRESTASI BELAJAR PENJASORKES MATERI LEMPAR TURBO MELALUI METODE TEAM GAME TOURNAMENT PADA SISWA KELAS V SEMESTER 2 SDN WONOREJO 1 KARANGANYAR DEMAK
}

\section{Suhartono $^{\bowtie}$}

SDN Wonorejo I Karanganyar Demak

Jawa Tengah, Indonesia

\section{Info Artikel}

Sejarah Artikel:

Diterima Oktober 2016

Disetujui Nvember 2016

Dipublikasikan Desember 2016

Keywords:

Throw Turbo, Learning

Physical Education and

Health, TGT

\begin{abstract}
The research problems are whether the use of the method TGT (Team Game Tournamen) or Gaming Team can improve learning achievement of Physical Education and Health (PEH) on the subject matter of the development of coordination numbers basic technique athletics (throwing turbo) at student Class V SD Negeri Wonorejo 1 Karanganyar Demak? The researches carried out by two cycles of the first cycle and the second cycle with each cycle consisting of planning, implementation, observation and reflection. Of the implementation cycle I and II obtained an average yield of 69.94 value before repairs, completeness 18 out of 32 students $(56.00 \%)$, the first cycle value - average 74.24, completeness 25 out of 32 students (77.00\%), the second cycle value-average 80.00 , completeness 30 from 32 students (95.00\%). From these results it can be concluded (i) an increase learning achievement PEH turbo throwing material through TGT method in class V students of SD Negeri Wonorejo 1 Academic Year 2015/2016.
\end{abstract}

\begin{abstract}
Abstrak
Rumusan masalah penelitian ini adalah apakah penggunaan metode TGT (Team Game Tournamen) atau Permainan Beregu dapat meningkatkan prestasi belajar Pendidikan Jasmani Olahraga dan Kesehatan (Penjasorkes) pada materi pokok pengembangan koordinasi beberapa nomor tehnik dasar atletik (lempar turbo) pada siswa Kelas V SD Negeri Wonorejo 1 Kecamatan Karanganyar Kabupaten Demak? Penelitihan ini dilaksanakan dengan dua siklus yaitu siklus I dan siklus II dengan masing-masing siklus terdiri dari tahap perencanaan, pelaksanaan, pengamatan dan refleksi. Dari pelaksanaan siklus I dan II diperoleh hasil rata-rata nilai sebelum perbaikan 69,94, ketuntasan 18 dari 32 siswa $(56,00 \%)$, siklus I nilai rata - rata 74,24, ketuntasan 25 dari 32 siswa (77,00\%), siklus II nilai rata - rata 80,00, ketuntasan 30 dari 32 siswa $(95,00 \%)$. Dari hasil tersebut dapat disimpulkan (i) terjadi peningkatan prestasi belajar Penjasorkes materi lempar turbo melalui metode TGT pada siswa kelas V SD Negeri Wonorejo 1 Tahun Pelajaran $2015 / 2016$.
\end{abstract}

Alamat korespondensi:

Program Studi Pendidikan Guru Sekolah Dasar

Fakultas Keguruan dan Ilmu Pendidikan Universitas Muria Kudus

Kampus UMK Gondangmanis, Bae Kudus Gd. L. It I PO. BOX 53

Kudus

Tlp (0291) 438229 ex.147 Fax. (0291) 437198

E-mail: hartonohidayat53@yahoo.co.id
p-ISSN 2087-9385

e-ISSN 2528-696X 


\section{PENDAHULUAN}

Pendidikan merupakan sarana bagi suatu bangsa untuk meningkatkan kualitas sumber daya manusia. Melalui pendidikan peserta didik diajarkan berbagai ilmu pengetahuan, dididik sesuai norma dan nilai-nilai yang berlaku serta dikembangkan potensi yang dimiliki untuk meningkatkan ilmu mutu pendidikan. Dalam praktiknya, upaya pe-ningkatan mutu pendidikan ini tidak mudah. Berbagai upaya telah dilaku-kan oleh pemerintah, melalui berbagai kebijakankebijakan dan peraturan, na-mun hasilnya pun masih belum mak-simal. Mutu pendidikan terkait erat de-ngan proses pembelajaran di sekolah. Proses pembelajaran sangat bergan-tung pada kemampuan guru dalam me-ngelola kelas sebagai subjek dan objek pembelajaran.

Berdasarkan penegasan di atas, dapat dikatakan bahwa guru adalah pemegang kunci keberhasilan mutu pen-didikan. Dalam PP No. 74 tahun 2008 tentang guru, guru didefinisikan sebagai pendidik profesional dengan tugas utama mendidik, mengajar, membim-bing, mengarahkan, melatih, menilai, dan mengevaluasi peserta didik pada pendidikan anak usia dini, jalur pendi-dikan formal, pendidikan dasar, dan pendidikan menengah. Guru harus me-miliki berbagai kompetensi meliputi kompetensi pedagogik, kompetensi ke-pribadian, kompetensi sosial, dan kom-petensi profesional yang diperoleh me-lalui pendidikan profesi.

Inovasi-inovasi yang dilakukan guru dalam tugasnya sebagai pendidik diharapkan mampu meningkatkan hasil belajar siswa. Mengingat bahwa guru juga memberi pengaruh terhadap hasil belajar siswa. Sebagaimana dikemuka-kan oleh Uno(2008) bahwa seorang guru sangat berpengaruh terhadap hasil belajar yang dapat ditunjukkan oleh peserta didiknya. Oleh karena itu peru-bahan-perubahan berkaitan dengan tugas mengajar guru harus selalu diting-katkan.

Pemilihan metode mengajar juga perlu diperhatikan karena tidak semua materi dapat diajarkan dengan hanya satu metode mengajar. Guru hendak-nya dapat memilih metode mengajar yang dianggap sesuai dengan materi yang hendak diajarkan. Hal ini dimaksudkan agar pengajaran khusus-nya mata pelajaran Pendidikan Jasma-ni, Olahraga dan Kesehatan (PJOK) dapat berlangsung secara efektif, efisien dan tidak membosankan.

Pendidikan Jasmani, Olahraga dan Kesehatan (Penjasorkes) merupakan mata pelajaran yang diwajibkan untuk kurikulum di jenjang pendidikan dasar, menengah, dan mata kuliah wajib untuk kurikulum pendidikan tinggi, sebagaimana yang diamanatkan dalam UndangUndang Nomor 20 Tahun 2003 tentang Sisdiknas pasal 37.

Berdasarkan hal tersebut Pendi-dikan Jasmani, Olahraga dan Kesehatan (Penjasorkes) tidak bisa dianggap remeh karena merupakan mata pelajaran yang diwajibkan, sehingga upayaupaya untuk memperbaiki proses pembelajaran Pendidikan Jasmani, Olahraga dan Kesehatan (Penjasorkes) di sekolah-sekolah maupun perguruan tinggi harus terus ditingkatkan.

Dari hasil observasi awal yang dilakukan terhadap siswa kelas V SD Negeri Wonorejo 1 Kecamatan Karanganyar Kabupaten Demak, penulis merasa masih ada kekurangan dalam pembelajaran Pendidikan Jasmani, Olahraga dan Kesehatan (Penjasorkes) dengan materi pokok pengembangan koor-dinasi beberapa nomor tehnik dasar atletik (lempar turbo). Hal tersebut terlihat dari rendahnya nilai rata-rata kelas hanya sebesar 69,94 dan rendahnya tingkat ketuntasan pengua-saan materi siswa sebesar $56,00 \%$ yang artinya dari 32 siswa hanya 14 siswa yang tuntas sedangkan yang 18 siswa sisanya belum tuntas. Ketuntasan siswa dalam belajar didasarkan pada nilai KKM setiap Kompetensi Dasar.

Berdasarkan permasalahan terse-but, penulis tertarik untuk melaksanakan penelitian tindakan kelas tentang Pengembangan Koordinasi Bebe-rapa Nomor Tehnik Dasar Atletik (Lempar Turbo) melalui Penggunaan Metode TGT (Team Game Tournamen) atau Permainan Beregu. Pembe-lajaran yang dilaksanakan menggunakan metode TGT (Team Game Tournamen) menjadikan pembelajaran lebih menyenangkan dan memotivasi siswa untuk aktif dalam pembelajaran, sehingga meningkatkan hasil belajar siswa.

\section{METODE PENELITIAN}

Subyek dalam penelitian ini adalah seluruh siswa Kelas V SD Negeri Wonorejo 1 Kecamatan Karanganyar Kabupaten Demak Tahun Pelajaran 2015/2016 yang berjumlah 32 siswa. Penelitian ini merupakan penelitian tindakan yang terdiri dari empat tahapan yaitu: perencanaan, pelaksanaan, pengamatan, dan refleksi (Arikunto, dkk: 2009). Prosedur PTK ini dilakukan dalam 2 siklus, setiap siklus terdiri dari satu pertemuan.

Sumber data penelitian ini ber-asal dari guru, siswa, dan data doku-men. Metode pengumpulan data yang digunakan yaitu melalui 
tes dan non tes. Variabel dalam penelitian ini meli-puti variabel masalah rendahnya hasil belajar siswa. Jenis data yang digu-nakan yaitu data kuantitatif. Teknik pengumpulan data dalam penelitian ini menggunakan teknik tes dan nontes yang terdiri dari observasi, catatan la-pangan, dan dokumentasi. Sedangkan teknik analisis data mengggunakan teknik analisis deskriptif kuantitatif dan kualitatif. Data kuantitatif berupa hasil belajar ranah kognitif dalam pembela-jaran penjasorkes dianalisis mengguna-kan teknik analisis deskriptif dengan menentukan skor berdasarkan proporsi, menghitung ketuntasan belajar secara klasikal, dan menghitung nilai ratarata kelas.

Data kualitatif berupa data hasil observasi aktivitas siswa dan hasil belajar ranah psikomotorik dalam pembelajaran penjasorkes materi lempar turbo menggunakan model TGT (Team Game Tournament). Hasil perhitungan dikelompokkan ke dalam 4 kategori yaitu sangat baik, baik, cukup, kurang. Adapun cara untuk mengolah data skor dan menentukan klasifikasinya menurut Aqib (2008) adalah sebagai berikut:

Rata-rata kelas $\mathrm{X}=\frac{\sum \mathrm{X}}{\sum \mathrm{N}}$

Keterangan :

$\mathrm{X}=$ nilai rata rata

$\sum X=$ jumlah semua nilai peserta didik

$\sum \mathrm{N}=$ jumlah peserta didik

\section{HASIL PENELITIAN DAN PEMBAHASAN Pra Siklus}

Sebelum penggunaan metode TGT (Team Game Tournamen) atau Permainan Beregu diperoleh nilai rata-rata prestasi belajar siswa adalah 69,94 dan ketuntasan belajar baru mencapai 56,00\% atau hanya ada 14 siswa dari 32 siswa yang sudah tuntas belajar. Hasil tersebut menunjukkan bahwa pada prasiklus secara klasikal siswa belum tuntas belajar, karena siswa yang memperoleh nilai $\geq 70$ hanya sebesar 56,00 $\%$ lebih kecil dari persentase ketuntasan yang dikehendaki yaitu sebesar 90\%. Hal ini disebabkan karena siswa masih me-ngalami kesulitan memahami materi. Secara lengkap hasil tersebut disajikan pada tabel berikut ini.

Tabel 1 Data Hasil Tes Formatif Pra Siklus

\begin{tabular}{lll}
\hline No & Uraian & $\begin{array}{l}\text { Hasil Pra } \\
\text { Siklus }\end{array}$ \\
\hline 1 & Jumlah Siswa & 32 \\
\hline
\end{tabular}

\begin{tabular}{lll}
\hline 2 & Jumlah Siswa Tuntas & 14 \\
\hline 3 & Jumlah Siswa Tidak Tuntas & 18 \\
\hline 4 & Tingkat Ketuntasan & $56,00 \%$ \\
\hline 5 & Rata-rata & 69,94 \\
\hline 6 & Nilai Tertinggi & 80 \\
\hline 7 & Nilai Terendah & 40 \\
\hline
\end{tabular}

Siklus I

Tabel 2 Data Hasil Tes Formatif Siklus I

\begin{tabular}{lll}
\hline No & Uraian & Siklus I \\
\hline 1 & Jumlah Siswa & 32 \\
\hline 2 & Jumlah Siswa Tuntas & 25 \\
\hline 3 & Jumlah Siswa Tidak Tuntas & 7 \\
\hline 4 & Tingkat Ketuntasan & $77,00 \%$ \\
\hline 5 & Rata-rata & 74,24 \\
\hline 6 & Nilai Tertinggi & 85 \\
\hline 7 & Nilai Terendah & 55 \\
\hline
\end{tabular}

Dari tabel di atas dapat digam-barkan bahwa dari pelaksanaan siklus I diperoleh hasil tingkat ketuntasan dan nilai rata-rata siswa yang sudah meningkat, namun masih memerlukan perbaikan karena belum sesuai dengan harapan yaitu tingkat ketuntasan 90\%. Dari 32 siswa hanya 25 siswa yang mencapai ketuntasan $(77,00 \%)$ dan seba-nyak $7 \quad(23,00 \%)$ siswa dinyatakan belum tuntas. Nilai rata-rata siswa juga bisa dikatakan sudah meningkat, yaitu sebesar 74,24. Nilai terendah yang diperoleh siswa terjadi peningkatan yaitu dari 40 meningkat menjadi 55 dan nilai tertinggi sudah mencapai 85 . Harapannya nilai terendah minimal sesuai KKM dan nilai tertinggi ada yang mencapai nilai 90 tidak hanya satu atau dua anak saja. Setelah penggunaan metode pem-belajaran TGT (Team Game Tournament) atau Permainan Beregu diperoleh nilai rata-rata prestasi belajar siswa adalah 74,24 dan ketuntasan belajar mencapai $77,00 \%$ atau sudah ada 25 siswa dari 32 siswa yang sudah tuntas belajar.Dari data ini dipeorleh hasil yang cenderung meningkat dibandingkan pada pra siklus.

\section{Siklus II}

Tabel 3 Data Hasil Tes Formatif Siklus II

\begin{tabular}{lll}
\hline No & Uraian & Siklus II \\
\hline 1 & Jumlah Siswa & 32 \\
\hline 2 & Jumlah Siswa Tuntas & 30 \\
\hline 3 & Jumlah Siswa Tidak Tuntas & 2 \\
\hline 4 & Tingkat Ketuntasan & $95,00 \%$ \\
\hline 5 & Rata-rata & 80,00 \\
\hline 6 & Nilai Tertinggi & 90 \\
\hline 7 & Nilai Terendah & 60 \\
\hline
\end{tabular}


Dari tabel di atas dapat dijelaskan bahwa dari pelaksanaan siklus II diperoleh hasil tingkat ketuntasan dan nilai rata-rata siswa mengalami pening-katan dan sudah sesuai dengan harapan yaitu tingkat ketuntasan 90\%. Dari 32 siswa, sebanyak 30 siswa $(95,00 \%)$ sudah mencapai ketuntasna belajar. Dengan demikian secara keseluruhan siswa sudah mencapai ketuntasan dan sesuai target yang diharapkan.

$$
\text { Rekapitulasi hasil peningkatan }
$$

keterampilan guru, aktivitas siswa, hasil belajar siswa disajikan dalam penjelasan berikut.

Tabel 1. Rekapitulasi Hasil Tes Siswa pra siklus, siklus I, dan II

\begin{tabular}{lllll}
\hline No & Uraian & $\begin{array}{l}\text { Pra } \\
\text { Siklus }\end{array}$ & $\begin{array}{l}\text { Hasil } \\
\text { Siklus } \\
\text { I }\end{array}$ & $\begin{array}{l}\text { Hasil } \\
\text { Siklus } \\
\text { II }\end{array}$ \\
\hline 1 & Jumlah Siswa & 32 & 32 & 32 \\
\hline 2 & $\begin{array}{l}\text { Jumlah Siswa } \\
\text { Tuntas }\end{array}$ & 14 & 25 & 30 \\
\hline 3 & $\begin{array}{l}\text { Jumlah Siswa } \\
\text { Tidak Tuntas }\end{array}$ & 18 & 7 & 2 \\
\hline 4 & Tingkat & $56 \%$ & $77 \%$ & $95 \%$ \\
& Ketuntasan & & & \\
\hline 5 & Rata-rata & 69,94 & 74,24 & 80,00 \\
\hline 6 & Nilai Tertinggi & 80 & 85 & 90 \\
\hline 7 & Nilai Terendah & 40 & 55 & 60 \\
\hline
\end{tabular}

Berdasarkan analisis data, diper-oleh aktivitas siswa dalam proses pembelajaran dalam setiap siklus meng-alami peningkatan. Hal ini berdampak positif terhadap prestasi belajar siswa yaitu dapat ditunjukkan dengan me-ningkatnya nilai rata-rata siswa pada setiap siklus. Pada siklus I terjadi peningkatan ketuntasan dari hanya 17 siswa yang tuntas menjadi 25 siswa yang tuntas, dan pada siklus II juga mengalami peningkatan ketuntasan dari 25 siswa menjadi 30 siswa yang tuntas.

Aktivitas siswa dalam proses pembelajaran Pendidikan Jasmani Olah-raga dan Kesehatan (PJOK) pada pokok bahasan pengembangan koor-dinasi beberapa nomor tehnik dasar atletik (lempar turbo) dengan metode pembelajaran $T G T$ (Team Game Tournamen) atau Permainan Beregu yang paling dominan adalah mende-

ngarkan/memperhatikan penjelasan gu-ru, dan kerja sama serta solidaritas yang tinggi untuk meraih kesuksesan bersama dalam pembelajaran sesuai dengan karakteristik metode pembela-jaran TGT (Team Game Tournamen) atau Permainan Beregu. Jadi dapat dikatakan bahwa aktivitas isiwa dapat dikategorikan aktif.
Dengan demikian, metode pem-belajaran TGT (Team Game Tournamen) atau Per-mainan Beregu sangat dibutuhkan guru untuk memperbaiki pembelajaran. Hal ini dimungkinkan karena metode tersebut lebih mene-kankan kepada tanggung jawab pribadi sebagai pribadi yang harus memahami materi dan menyelesaikan suatu tugas secara tuntas dalam kelompoknya.

Sebagaimana dijelaskan dalam teori, bahwa metode tersebut dapat memberi motivasi lebih kepada siswa untuk terlibat aktif dalam usaha untuk bekerja sama dan saling membantu antar temannya dalam belajar sehingga mereka dapat membangun sendiri pemahaman secara bersama-sama.

Pada penggunaan metode pem-belajaran TGT (Team Game Tour-namen) atau Permainan Beregu diper-oleh temuan bahwa metode TGT (Team Game Tournamen) atau Perma-inan Beregu dapat meningkatkan pe-mahaman siswa dalam menyelesaikan berbagai permasalahan pengembangan koordinasi beberapa nomor tehnik da-sar atletik (lempar turbo) di mana mate-ri pengembangan koordinasi beberapa nomor tehnik dasar atletik (lempar turbo) membutuhkan konsep-konsep yang sederhana akan tetapi sangat luas makna dan cakupannya. Sehingga de-ngan menggunakan metode TGT (Team Game Tournamen) atau Perma-inan Beregu, siswa diharapkan dapat lebih memahami materi tersebut. Di samping itu, proses pembelajaran berlangsung lebih hidup dan menarik. Sebagian besar siswa sangat antusias mengikuti proses pembelajaran. Keak-tifan siswa sangat terlihat saat siswa antusias bekerja sama untuk meraih point maksimal dengan menggunakan metode TGT (Team Game Tournamen) atau Permainan Beregu.

Melalui metode ini, siswa yang sebelumnya belajar secara individu, tanpa kompetisi dan pennghargaan ke-mudian dikondisikan dengan adanya kompetisi dan penghargaan yang men-jadi motivasi bagi keberhasilan belajar mereka dan suasana pembelajaran da-pat berlangsung lebih menarik dan ber-variasi tidak monoton. Rasa percaya di-ri siswa juga meningkat karena siswa dikondisikan untuk menyampaikan ide dan pendapat.

\section{SIMPULAN}

Metode pembelajaran TGT (Team Game Tournamen) atau Perma-inan Beregu dapat meningkatkan pres-tasi belajar Pendidikan 
Jasmani Olahra-ga dan Kesehatan (Penjasorkes) tentang Pengembangan koordinasi beberapa nomor tehnik dasar atletik (lempar turbo) pada siswa Kelas V SD Negeri Wonorejo 1 Kecamatan Karang-anyar Kabupaten Demak semester 2 tahun pelajaran 2015/2016.

Guru diharapkan memiliki ke-mampuan dan pengetahuan yang cukup untuk memilih metode pembelajaran yang sesuai dengan karakteristik siswa serta mata pelajaran yang manjadi po-kok bahasan sehingga dapat meningkatkan hasil belajar, salah satunya ada-lah metode pembelajaran TGT (Team Game Tournamen) atau Permainan Beregu. Guru hendaknya membiasakan diri untuk melakukan perbaikan pembelajaran apabila ketuntasan siswa masih jauh dari yang diharapkan dengan mencoba berbagai variasi metode dan model pembelajaran yang sesuai dengan karakteristik siswa.

\section{DAFTAR PUSTAKA}

Aqib, Zainal. 2009. Penelitian Tindakan Kelas. Bandung : Yrama Media.

Belajar.https://id.wikipedia.org/wiki/belajar diakses tanggal 13/08/2014

Departeman Agama RI. 2004. Kurikulum Madrasah Ibtidaiyah (Standart Kompetensi). Jakarta. Departemen Pendidikan Nasional. 2007. Kamus Besar Bahasa Indonesia. Jakarta: Balai Pustaka.

Hamalik, Oemar. 2011. Kurikulum dan Pembelajaran. Jakarta: Bumi Aksara

Harahap, Nasrun. 1994. Penilaian Hasil Belajar. Surabaya : Usaha Nasional

Heruman. 2007. Model Pembelajaran Pendidikan Jasmani Olahraga dan Kesehatan (PJOK). Bandung: PT. Remaja Rosdakarya.

Heruman. 1990. Model Pembelajaran Pendidikan Jasmani Olahraga dan Kesehatan (PJOK) Sekolah Dasar. Malang: IKIP Malang.

Lumintuarso, Ria. 2008. Peralatan Olahraga Anak untuk Pengembangan Multilateral. Jakarta : Depdiknas.
Purwanto. 2009. Evaluasi Hasil Belajar. Yogyakarta: Pustaka Pelajar.

Slameto. 2003. Belajar dan Faktor-faktor yang Mempengaruhinya. Jakarta: Rineka Cipta 